EXPERIMENTAL STUDY

\title{
Inhibition of pituitary type 2 deiodinase by reverse triiodothyronine does not alter thyroxine-induced inhibition of thyrotropin secretion in hypothyroid rats
}

\author{
P Cettour-Rose, T J Visser ${ }^{1}$, A G Burger and F Rohner-Jeanrenaud \\ Division of Endocrinology, Diabetology and Nutrition, Department of Internal Medicine, University Medical Center, Faculty of Medicine, University of \\ Geneva, 1211 Geneva 4, Switzerland and ${ }^{1}$ Internal Medicine III, Erasmus University Medical Center, 3015 GE Rotterdam, Netherlands \\ (Correspondence should be addressed to F Rohner-Jeanrenaud; Email: Francoise.Jeanrenaud@medecine.unige.ch)
}

\begin{abstract}
Objectives: Intrapituitary triiodothyronine (T3) production plays a pivotal role in the control of TSH secretion. Its production is increased in the presence of decreased serum thyroxine (T4) concentrations and the enzyme responsible, deiodinase type 2 (D2), is highest in hypothyroidism. In order to document the role of this enzyme in adult rats we developed an experimental model that inhibited this enzyme using the specific inhibitor, reverse T3 (rT3).

Methods: Hypothyroidism was induced with propylthiouracil (PTU; $0.025 \mathrm{~g} / \mathrm{l}$ in drinking water) which in addition blocked deiodinase type 1 (D1) activity, responsible for the rapid clearance of rT3 in vivo. During the last 7 days of the experiment, the hypothyroid rats were injected (s.c.) for 4 days with 0.4 or $0.8 \mathrm{nmol} \mathrm{T} 4$ per $100 \mathrm{~g}$ body weight (bw) per day. For the last 3 days, the same amount of T4 was infused via s.c. minipumps. In additional groups, $25 \mathrm{nmol} \mathrm{rT3/100 \textrm {g } b w}$ per day were added to the 3-day infusion of T4.

Results: Infusion of $0.4 \mathrm{nmol} \mathrm{T} 4 / 100 \mathrm{~g}$ bw per day did not affect the high serum TSH levels, $0.8 \mathrm{nmol}$ T4/100 g bw per day decreased them to $57 \%$ of the hypothyroid values. The infusions of rT3 inhibited D2 activity in all organs where it was measured: the pituitary, brain cortex and brown adipose tissue (BAT). In the pituitary, the activity was $27 \%$, to less than $15 \%$ of the activity in hypothyroidism. Despite that, serum TSH levels did not increase, serum T4 concentrations did not change and the changes in serum T3 were minimal.

Conclusions: We conclude that in partly hypothyroid rats, a 3-day inhibition of D2 activity, without concomitant change in serum T4 and minimal changes in serum T3 levels, is not able to upregulate TSH secretion and we postulate that this may be a reflection of absent or only minimal changes in circulating T3 concentrations.
\end{abstract}

European Journal of Endocrinology 153 429-434

\section{Introduction}

Pituitary triiodothyronine (T3) concentration is the main inhibitor of thyroid-stimulating hormone (TSH) secretion. Its concentration is finely tuned by the intrapituitary conversion of thyroxine (T4) to T3 and by the serum T3 concentrations. Much attention has been given to the local mechanisms controlling this conversion. It is mainly dependent on deiodinase type 2 (D2) activity. This has been documented by many studies, particularly those involving genetically modified mice bearing a mutation of the D2 gene and experiments with large doses of $\mathrm{T} 4$. In the latter studies, a large bolus of T4 was only able to inhibit TSH secretion if pituitary D2 activity was fully active, strongly supporting the concept of a crucial role of D2 in the control of TSH secretion in normal rats $(1-4)$.
The aim of the present work was to study, in adult rats, the consequences of an inhibition of pituitary D2 activity on serum TSH concentrations. We used hypothyroid rats substituted with small amounts of T4. Inhibition of D2 activity was obtained by infusing reverse T3 (rT3), a specific inhibitor of this enzyme (but not of its mRNA). In vivo, rT3 is rapidly metabolized, mainly by D1. We therefore used propylthiouracil (PTU) for inducing hypothyroidism since it inhibits D1 activity at the same time. The infusion of rT3 resulted therefore in high serum rT3 levels.

\section{Materials and methods}

\section{Animals}

Eight- to nine-week-old male Wistar rats purchased from BRL (Basle, Switzerland) were housed under 
conditions of controlled temperature $\left(23^{\circ} \mathrm{C}\right)$ and illumination $(0700-1900 \mathrm{~h})$. They had access to water and standard laboratory chow (Provimi Lacta SA, Cossonay, Switzerland) and were allowed to feed ad libitum.

\section{Experimental procedures}

Animals were made hypothyroid with PTU (Fluka Chemie, Buchs, Switzerland) given in their drinking water at a dose of $0.025 \mathrm{~g} / \mathrm{l}$. In preliminary experiments this dose inhibited hepatic D1 activity to $10 \%$ of the euthyroid activity (see Table 2) without affecting fluid and food intake. After 2 weeks, the rats were divided into four groups of five to ten animals which were assigned different treatments (Fig. 1). In one group, PTU treatment was stopped 10 days before animals were killed, leading to normalization of thyroid function (euthyroid rats). One group was only treated with PTU (hypothyroid rats). The other groups received $\mathrm{T} 4$ s.c. once a day for 4 days, followed by 3 days of constant s.c. infusion via osmotic minipumps (Model 2001, Alza Corporation, Palto Alto, CA, USA) with or without concomitant rT3 administration.

These experiments were done three times with different $\mathrm{T} 4$ substitution rates. In the first experiment, 0.4 and $0.8 \mathrm{nmol}$ per $100 \mathrm{~g}$ body weight (bw) per day of T4 were infused (total of six groups of animals). In the second experiment, $0.4 \mathrm{nmol} / 100 \mathrm{~g}$ bw per day and in the third experiment, $0.8 \mathrm{nmol} / 100 \mathrm{~g}$ bw per day were infused (four groups of animals per experiment). rT3 was always infused at the rate of $25 \mathrm{nmol} / 100 \mathrm{~g}$ bw per day.

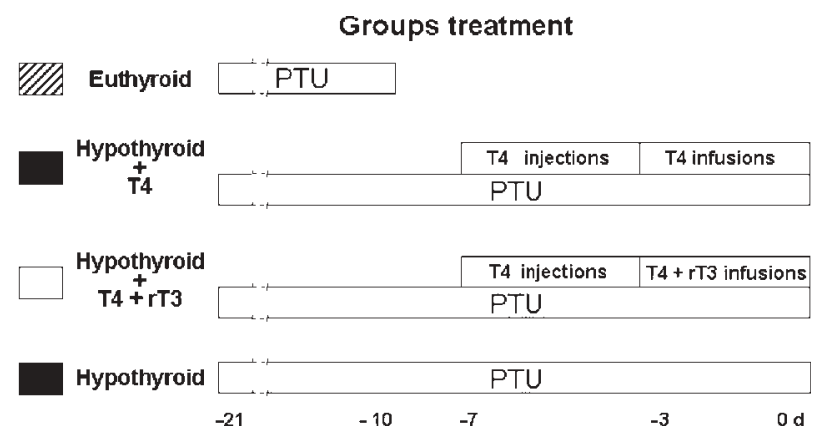

Figure 1 Three experiments were performed. Each experiment consisted of a euthyroid control group (stopping PTU 10 days before T4 administration), one hypothyroid group receiving T4 and one receiving in addition rT3 during the last 3 days. A nonsubstituted hypothyroid group was also included. In experiment 1 , 0.4 and $0.8 \mathrm{nmol} \mathrm{T} 4 / 100 \mathrm{~g}$ bw per day were infused; in experiments 2 and $3,0.4$ and $0.8 \mathrm{nmol} \mathrm{T} 4 / 100 \mathrm{~g}$ bw per day were given, respectively. The infusion of rT3 was always $25 \mathrm{nmol} / 100 \mathrm{~g}$ bw per day. In experiment 1, there were six groups of six of animals per group; in experiments 2 and 3 , there were four groups of five to eight animals. The symbols on the left of the figure are used throughout in this paper.

\section{Thyroid hormone administration}

L-T4 (T4; 1 mg; Henning, Berlin, Germany) or L-rT3 (rT3; $4 \mathrm{mg}$; Formula, Berlin, Germany) were dissolved in $0.1 \mathrm{M} \mathrm{NaOH}$ and further diluted to the final concentration with $0.02 \mathrm{M} \mathrm{NaOH}$ in $0.9 \% \mathrm{NaCl}$ and $0.5 \%$ hypothyroid rat serum.

\section{Deiodinase activities}

Tissues were homogenized in 10 volumes of $0.1 \mathrm{M}$ phosphate (pH 7.2), 2 mM EDTA and $1 \mathrm{mM}$ dithiothreitol (DTT) (abbreviated as P100E2D1 buffer). D2 activity was assayed in freshly prepared homogenates. Aliquots of homogenates were snap-frozen and stored at $-80^{\circ} \mathrm{C}$ until analysis of enzyme activities. D1 and D2 activities were assayed by monitoring the release of radioiodide from outer-ring labeled rT3 and T4, respectively (5). For hepatic D1 activity, liver homogenates $(\sim 50 \mu \mathrm{g}$ protein $/ \mathrm{ml})$ were incubated for $30 \mathrm{~min}$ at $37^{\circ} \mathrm{C}$ with $0.1 \mu \mathrm{M} \mathrm{rT} 3$ and $10^{5}$ c.p.m. $\left[3^{\prime}, 5^{\prime}-{ }^{125} \mathrm{I}\right] \mathrm{rT} 3$ in $0.1 \mathrm{ml}$ P100E2D10 buffer. Blank incubations were carried out in the absence of homogenate. Radioiodide production was analyzed as previously described (6). Deiodinase activity of homogenates was corrected for nonenzymatic deiodination observed in the blanks. D2 activities in brain, pituitary and brown adipose tissue (BAT) were determined by incubation of the homogenates for $60 \mathrm{~min}$ at $37^{\circ} \mathrm{C}$ with $1 \mathrm{nM}$ $\left(10^{5}\right.$ c.p.m.) $\left[3^{\prime}, 5^{\prime}-{ }^{125} \mathrm{I}\right] \mathrm{T} 4$ in the presence of $0.1 \mu \mathrm{M}$ T3 to block D3 and 0.1 mM PTU to block D1, if present. The protein concentration of the pituitary homogenate was approximately $0.25 \mathrm{mg} / \mathrm{ml}$, the final dilution in the assay being 1/400. Blank incubations were carried out in the absence of homogenate. Release of ${ }^{125} \mathrm{I}$ was determined and corrected for nonenzymatic deiodination as described above. In the assays of D1 and D2 activities, the samples were highly diluted (4000 times for liver and 400 times for pituitary homogenates) excluding a possible in vitro effect of the PTU or rT3.

\section{Serum hormones and metabolites}

TSH and T4 levels were measured by immunoradio metro assay (IRMA) (Immulite 2000, Diagnostic Product Corporation, Los Angeles, CA, USA; kit reference for rat TSH is L2KTS6 and for T4, L2KT4). Serum T3 and rT3 levels were measured by in-house methods in Rotterdam (Erasmus University, Rotterdam, the Netherlands) with the following respective intra- and interassay coefficients of variation: T3, 2-6\% and $8 \%$; rT3, 3$4 \%$ and $9-14 \%$. More specifically, T3 was measured by RIA using a rabbit anti-T3 antiserum (final dilution 1:250 000) and [ $\left.{ }^{125} \mathrm{I}\right] \mathrm{T} 3$ (20000 c.p.m.) (Amersham). Sample volume was $25 \mu \mathrm{l}$, and incubation mixtures were prepared in $1 \mathrm{ml}$ of RIA buffer $(0.06 \mathrm{M}$ barbital, 
$0.15 \mathrm{M} \mathrm{HCl}, 0.1 \%$ BSA and $0.6 \mathrm{~g} / \mathrm{l}$ 8-anilino-1naphthalenesulfonic acid (Sigma)). Mixtures were incubated in duplicate overnight at $4^{\circ} \mathrm{C}$, and antibodybound radioactivity was precipitated using Sac-Cel cellulose-coupled second antibody (IDS, Boldon, UK). The lower limit of detection was $0.15 \mathrm{nmol} / \mathrm{l}$. Serum rT3 levels were determined using an antiserum produced in-house. The limit of detection was $0.04 \mathrm{nmol} / \mathrm{l} \mathrm{rT} 3$.

\section{Statistical analysis}

The results were analyzed by one-way ANOVA followed by the Tukey procedure for multiple comparisons. The calculations were performed using the Sigma STAT software (SPSS Inc., Chicago, IL, USA). A $P$ value $<0.05$ was considered statistically significant.

\section{Results}

The main purpose of the experiments was to compare serum TSH concentrations with and without specific inhibition of pituitary D2 activity by rT3 (Fig. 1). This was obtained without any change in $\mathrm{T} 4$ infusion rates. A model of partial hypothyroidism was used providing some $\mathrm{T} 4$ as substrate and avoiding extreme stimulation of serum TSH. Two T4 infusion rates, 0.4 and $0.8 \mathrm{nmol} / 100 \mathrm{~g}$ bw per day were chosen. They were only performed simultaneously in the first experiment, in the second experiment $0.4 \mathrm{nmol} / 100 \mathrm{~g} \mathrm{bw}$ per day of T4 were infused and in the third experiment $0.8 \mathrm{nmol} / 100 \mathrm{~g} \mathrm{bw}$ per day were infused. Statistical evaluation of the serum T4, T3 and TSH levels in the separate experiments showed no difference in the results. Therefore, for identical infusion rates, we pooled the values of the three experiments. The pituitary D2 activities of experiment 1 are given in Fig. 2.

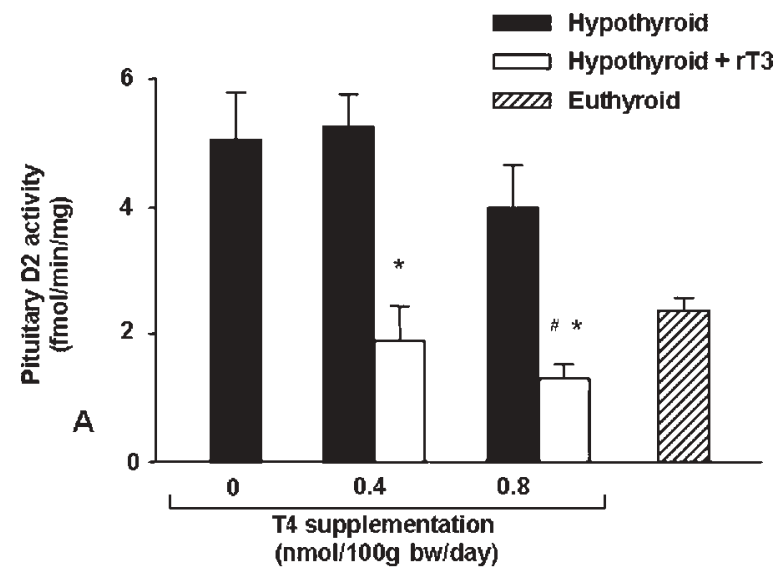

Figure 2 In experiment 1, pituitary D2 activity in fmol/min per $\mathrm{mg}$ was measured in groups of five to eight euthyroid and hypothyroid rats receiving no, 0.4 or $0.8 \mathrm{nmol} T 4 / 100 \mathrm{~g}$ bw per day with or without concomitant rT3 infusion. Absolute activities are given. ${ }^{\star} P<0.01$ versus the hypothyroid group; ${ }^{\#} P<0.05$ versus euthyroid; results are means \pm S.E.M.
Table 1 shows the percentage changes for all three experiments since the absolute values showed considerable differences (untreated hypothyroid values: $19 \pm 5 \mathrm{fmol} / \mathrm{ml}$ per $\mathrm{min}$ )

Without rT3, only $0.8 \mathrm{nmol}$ T4 was able to inhibit significantly pituitary D2 activity, to $68 \%$ of the hypothyroid control value. In both cases, additional infusion of rT3 decreased this enzyme activity to less than found in the corresponding euthyroid groups (Table 1 and Fig. 2). Under 0.4 nmol T4/100 g bw per day, the remaining activity was $24-38 \%$ of the hypothyroid control and under $0.8 \mathrm{nmol}$ it was $19-26 \%$ of the hypothyroid control.

Without the addition of $\mathrm{rT} 3$, the infusion rate of 0.4 nmol T4/100 g bw per day was not sufficient to inhibit the TSH levels while $0.8 \mathrm{nmol}$ decreased serum TSH levels to $57 \%$ of the hypothyroid rats. Figure 3 illustrates the mean serum TSH concentrations of the three experiments: despite the marked inhibition of D2 activity by the rT3 infusions, no increase in serum TSH levels could be seen. Such an increase would be expected if the intrapituitary D2 activity was rate limiting and the only control mechanism of TSH secretion.

In the hypothyroid state, serum $\mathrm{T} 4$ levels were undetectable, serum T3 levels were $0.13 \pm 0.02 \mathrm{nmol} / \mathrm{l}$ or $8.3 \%$ of those of euthyroid rats.

With $0.4 \mathrm{nmol} \mathrm{T} 4 / 100 \mathrm{~g}$ bw per day, T4 levels were $34.9 \pm 1.9 \mathrm{nmol} / \mathrm{l}$. The additional infusion of rT3 did not change serum T4 levels. Yet with rT3, there was a moderate but significant decrease in serum T3 levels from $0.44 \pm 0.03$ to $0.30 \pm 0.04 \mathrm{nmol} / \mathrm{l}$ probably due to the small remaining D1 activity.

With the infusion of $0.8 \mathrm{nmol} \mathrm{T} 4 / 100 \mathrm{~g}$ bw per day, serum T4 levels were slightly above those of euthyroid rats $(82.59 \pm 2.02 \mathrm{nmol} / \mathrm{l})$, reflecting the reduced $\mathrm{T} 4$ metabolism due to the PTU treatment. Serum T3 levels $(0.58 \pm 0.04 \mathrm{nmol} / \mathrm{l})$ were slightly above those obtained with infusions of $0.4 \mathrm{nmol} \mathrm{T} 4 / 100 \mathrm{~g}$ bw per day, probably reflecting some remaining D1 activity. Similarly to the T4 levels obtained with the infusion of $0.4 \mathrm{nmol} \mathrm{T} 4 / 100 \mathrm{~g}$ bw per day, no changes were seen in serum T4 levels under rT3 infusion. Yet serum T3 levels were no more affected by rT3 infusion (0.55 $0.04 \mathrm{nmol} / \mathrm{l})$ (Fig. 4).

The inhibition of D2 activity by rT3 was not limited to the pituitary. It was even more marked in the cerebral cortex and in BAT (Table 2). The values of these enzyme activities are given to provide evidence for the ubiquitous character of the inhibitory effect of rT3 infusions when high serum concentrations can be maintained over days. The effectiveness of PTU for inhibiting hepatic D1 activity is also shown in Table 2. It was only $6-15 \%$ of the activity in euthyroid rats. rT3 infusions did not affect D1 enzyme activity.

The euthyroid control rats obtained by stopping PTU treatment 10 days before the animals were killed (Fig. 1) had normalized their serum T4 
Table 1 Effects of hypothyroidism, T4 substitution and rT3 infusion on pituitary D2 activity.

\begin{tabular}{|c|c|c|c|c|c|c|}
\hline \multirow{2}{*}{$\begin{array}{l}\text { PTU in drinking water } \\
\text { T4 supplementation } \\
\text { (nmol/100 g bw per day) } \\
\text { rT3 }(25 \mathrm{nmol} / 100 \mathrm{~g} \text { bw per day) }\end{array}$} & \multicolumn{5}{|c|}{ Hypothyroid } & Euthyroid \\
\hline & $\begin{array}{l}+ \\
0\end{array}$ & $\begin{array}{l}+ \\
0.4\end{array}$ & $\begin{array}{l}+ \\
0.4 \\
+\end{array}$ & $\begin{array}{l}+ \\
0.8\end{array}$ & $\begin{array}{l}+ \\
0.8 \\
+\end{array}$ & $\begin{array}{l}- \\
- \\
-\end{array}$ \\
\hline \multicolumn{7}{|c|}{ Pituitary D2 activity (\% of PTU alone) } \\
\hline $\begin{array}{l}\text { Experiment } 1 \\
\text { Experiment } 2 \\
\text { Experiment } 3\end{array}$ & $\begin{array}{l}100.0 \pm 15.59 \\
100.0 \pm 4.47 \\
100.0 \pm 6.21\end{array}$ & $\begin{array}{r}104.02 \pm 9.42 \\
90.62 \pm 6.02\end{array}$ & $\begin{array}{l}37.51 \pm 10.57^{* \#} \\
23.89 \pm 1.71^{* \# \S}\end{array}$ & $\begin{array}{l}78.99 \pm 13.18 \\
68.40 \pm 6.73^{*}\end{array}$ & $\begin{array}{l}25.70 \pm 4.25^{\star \# \S} \\
18.91 \pm 4.15^{\star \# \S}\end{array}$ & $\begin{array}{l}46.67 \pm 4.94^{*} \\
38.60 \pm 4.91^{*} \\
31.03 \pm 1.92^{*}\end{array}$ \\
\hline
\end{tabular}

When infused, rT3 was given together with T4 infusion during the 3 days before animals were killed. The results are represented as the percentage remaining activity compared with the PTU-treated hypothyroid rats that did not receive any T4. The mean activity of these three hypothyroid groups was $19 \pm 5 \mathrm{fmol} / \mathrm{ml}$ per min. The last column represents the results obtained in the rats where PTU was stopped 10 days before animals were killed (euthyroid rats). Statistical significance: ${ }^{\S} P$ at least $<0.05$ versus the euthyroid group; ${ }^{\star} P$ at least $<0.05$ versus the hypothyroid group; ${ }^{\#} P$ at least $<0.05$ versus its respective T4-supplemented group. Results are means \pm S.E.M.

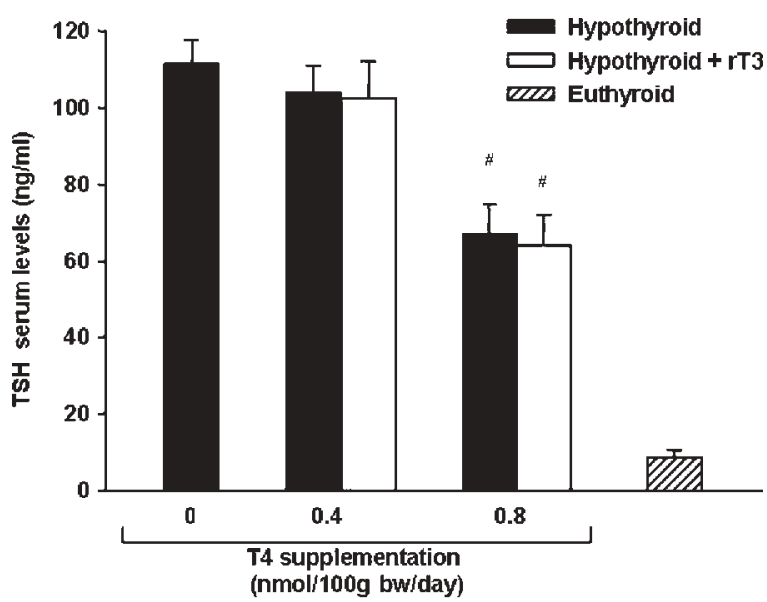

Figure 3 Serum TSH levels measured in groups of five to eight euthyroid and hypothyroid rats receiving no, 0.4 or $0.8 \mathrm{nmol}$ $\mathrm{T} 4 / 100 \mathrm{~g}$ bw per day with or without concomitant rT3 infusion. The results of the three experiments were pooled. ${ }^{\#} P<0.01$ compared with the hypothyroid group; results are means \pm S.E.M.

$(67.4 \pm 5.7 \mathrm{nmol} / \mathrm{l})$, T3 $(1.55 \pm 0.06 \mathrm{nmol} / \mathrm{l})$ and TSH $(8.6 \pm 1.6 \mathrm{ng} / \mathrm{ml})$ values but their weights were not yet significantly different from the hypothyroid group $(169.3 \pm 4.2 \mathrm{~g}$ vs $170.6 \pm 3.0 \mathrm{~g})$.

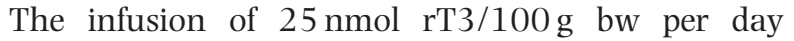
resulted in a mean serum rT3 concentration of $90 \pm 7 \mathrm{nmol} / \mathrm{l}$, which was $8-9$ times higher than in experiments where we used methimazole (MMI) instead of PTU to induce hypothyroidism.

\section{Discussion}

D2 activity is crucial for the autonomous cellular control of T3 production $(2,4,7,8)$. This has been proven in many situations: in the acute control of serum TSH, during development, in particular for the development of the central nervous system and for tadpole metamorphosis (9-11). Pituitary D2 activity increases with decreasing serum T4 concentrations and is highest in
A
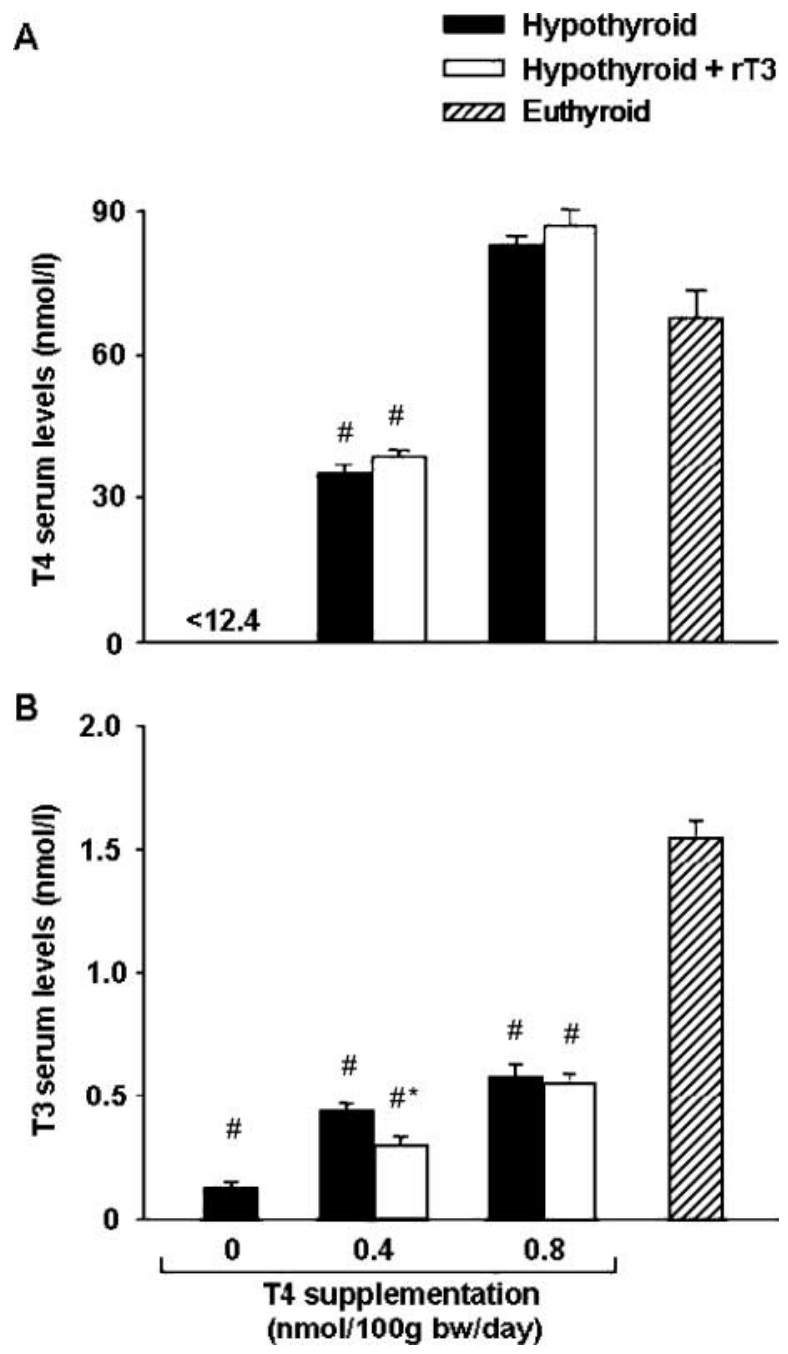

Figure 4 T4 (A) and T3 (B) serum levels measured in groups of five to eight euthyroid and hypothyroid rats receiving no, 0.4 or $0.8 \mathrm{nmol}$ T4/100 $\mathrm{g}$ bw per day with or without concomitant rT3 infusion. The mean values ( \pm S.E.M.) of experiments 1,2 and 3 are shown. $P$ at least $<0.05$ versus the euthyroid group; ${ }^{*} P$ at least $<0.05$ versus its respective hypothyroid T4-supplemented group. 
hypothyroidism. Our experiments were based on the assumption that D2 activity plays a very important role for the intermediate-term (3 days) regulation of pituitary TSH secretion in adult hypothyroidism and still plays a significant role in euthyroidism. If the inhibition of serum TSH levels is mainly a reflection of pituitary T3 generated by local D2 activity, one would expect that in severe to moderate hypothyroidism, inhibition of this enzyme activity would decrease local T3 production and further increase serum TSH levels. Unfortunately it is not possible to measure the fluctuations of intrapituitary T3 concentrations, yet our results indicate that there is no close correlation between pituitary D2 activity and serum TSH levels.

Our results do not allow generalizations since they are probably bound to the experimental conditions that were chosen. What are the possible experimental differences with other published work? The strongest evidence for a crucial role of D2 comes from its knockout mice (12). These animals have normal serum T3 levels, twice normal serum $\mathrm{T} 4$ and increased serum TSH levels, indicating that in these mice, in order to normalize serum T3 levels, the absent conversion of T4 to T3 by D2 is overcome by increasing serum TSH and T4 levels. Like normal mice treated with MMI, these mice further increased serum TSH levels under MMI. In these mice exogenous T3 infusion inhibits TSH secretion, but even large doses of T4 failed to do so. This confirms the importance of T3 and D2 in the control of TSH secretion (12). Our model differs from the knockout mouse in that we used normal adult rats and induced only a transient inhibition of this enzyme. Also, rT3 inhibits only the activity of the enzyme, but not mRNA levels. Another difference resides in the fact that in our case, the activity was not completely abolished. It is well known that even in genetically modified mice, the phenotypes of partial deletions are often very similar to wild-type animals and markedly different from complete deletions. Finally, in the D2 knockout mice D1 activity is normal while here it is strongly inhibited.

The first experiments pointing to a crucial role of D2 in the control of TSH were performed in adult rats (1). These short-term experiments clearly showed that this enzyme was essential for the control of TSH if a large bolus of T4 was administered. They showed that the inhibitory effect of a bolus injection of T4 was abolished if a non-specific inhibitor of the three deiodinases, iopanoic acid, was administered; however, this effect was not abolished if one gave the specific inhibitor of D1, PTU. By exclusion, the inhibition of D2 activity by iopanoic acid had to be responsible for these findings. Even though these experiments leave no doubt as to a crucial role of D2, they reflect the changes of D2 activity minutes to some few hours after the injection of $\mathrm{T} 4$. In contrast to the studies of Larsen et al. (1), we were not studying acute TSH inhibition by a bolus of T4. We studied the changes in serum TSH under a constant, 3-day infusion of T4. During that time, intrapituitary D2 activity was strongly inhibited by concomitant infusion of rT3. Our results suggest that under such experimental conditions, partial inhibition of D2 does not result in an increase in serum TSH. In this respect, the barely changed serum T3 levels indicate that thyroidal status of peripheral organs such as heart and liver did not change. It is therefore possible that this information can be read centrally, inducing compensatory mechanisms, particularly if the situation prevails for 3 days. Such mechanisms would have to be mediated via hypothalamic pathways. At the present time this postulate remains purely speculative. It is however interesting to cite two articles where rT3 was given to humans (13, 14). In one article, the amounts of rT3 given were very high ( $3 \mathrm{mg} /$ day). Despite that, no change in basal or TRH-stimulated TSH concentrations could be induced with this treatment (14).

In conclusion, we demonstrate that in PTU-induced hypothyroid rats, increasing the infusion from 0.4 to

Table 2 Effects of hypothyroidism, T4 substitution and rT3 infusion on D1 and D2 activities.

\begin{tabular}{|c|c|c|c|c|c|c|}
\hline \multirow[b]{2}{*}{$\begin{array}{l}\text { PTU treatment } \\
\text { T4 supplementation ( } \mathrm{nmol} / 100 \mathrm{~g} \text { bw per day) } \\
\mathrm{rT3} \text { infusion } 25 \mathrm{nmol} / 100 \mathrm{~g} \text { bw per day }\end{array}$} & \multicolumn{5}{|c|}{ Hypothyroid } & \multirow{2}{*}{$\begin{array}{c}\text { Euthyroid } \\
- \\
-\end{array}$} \\
\hline & $\begin{array}{l}+ \\
0 \\
-\end{array}$ & $\begin{array}{c}+ \\
0.4 \\
-\end{array}$ & $\begin{array}{l}+ \\
0.4 \\
+\end{array}$ & $\begin{array}{l}+ \\
0.8 \\
-\end{array}$ & $\begin{array}{l}+ \\
0.8 \\
+\end{array}$ & \\
\hline \multicolumn{7}{|l|}{ Liver D1 activity (pmol/ml per min) } \\
\hline $\begin{array}{l}\text { Experiment } 2 \\
\text { Experiment } 3\end{array}$ & $\begin{array}{l}2.18 \pm 0.17^{\S} \\
3.35 \pm 0.82^{\S}\end{array}$ & $2.92 \pm 0.15^{\S}$ & $2.42 \pm 0.11^{\S}$ & $8.13 \pm 0.58^{\S *}$ & $6.08 \pm 0.50^{\S *}$ & $\begin{array}{l}22.88 \pm 1.32 \\
55.57 \pm 4.18\end{array}$ \\
\hline \multicolumn{7}{|l|}{ BAT D2 activity (fmol/ml per min) } \\
\hline $\begin{array}{l}\text { Experiment } 1 \\
\text { Experiment } 2 \\
\text { Experiment } 3\end{array}$ & $\begin{array}{l}6.81 \pm 0.69 \\
3.78 \pm 0.40 \\
7.88 \pm 1.91\end{array}$ & $\begin{array}{l}2.66 \pm 0.57^{*} \\
1.56 \pm 0.37^{\star} \\
-\end{array}$ & $\begin{array}{l}0.63 \pm 0.10^{*} \\
0.67 \pm 0.12^{\star \#} \\
-\end{array}$ & $\begin{array}{c}3.51 \pm 0.50^{*} \\
- \\
0.49 \pm 0.14^{*}\end{array}$ & $\begin{array}{c}1.84 \pm 0.35^{*} \\
- \\
0.85 \pm 0.35^{\star}\end{array}$ & $\begin{array}{l}2.05 \pm 0.18 \\
0.74 \pm 0.16^{\star} \\
1.18 \pm 0.30^{*}\end{array}$ \\
\hline \multicolumn{7}{|l|}{ Cerebral cortex D2 activity (fmol/ml per min) } \\
\hline $\begin{array}{l}\text { Experiment } 2 \\
\text { Experiment } 3\end{array}$ & $\begin{array}{l}2.33 \pm 0.06 \\
5.32 \pm 0.32\end{array}$ & $\begin{array}{c}0.65 \pm 0.09^{*} \\
-\end{array}$ & $\begin{array}{c}0.14 \pm 0.01^{\star \#} \\
-\end{array}$ & $\overline{-} \overline{-}\left(0.02^{*}\right.$ & $\overline{0.23 \pm 0.03^{*}}$ & $\begin{array}{l}0.33 \pm 0.05 \\
0.52 \pm 0.09\end{array}$ \\
\hline
\end{tabular}

For experimental design see Table 1 and Fig. 1 . Statistical significance: ${ }^{\S} P$ at least $<0.05$ versus the euthyroid group; ${ }^{\star} P$ at least $<0.05$ versus the hypothyroid group; ${ }^{P} P$ at least $<0.05$ versus its respective T4-supplemented group. Results are means \pm S.E.M. 
$0.8 \mathrm{nmol} \mathrm{T} 4 / 100 \mathrm{~g}$ bw per day resulted in a significant inhibition of serum TSH and pituitary D2 activity. At the same time, serum T4 concentrations increased from 35 to $83 \mathrm{nmol} / \mathrm{l}$ and serum T3 concentrations from 0.44 to $0.58 \mathrm{nmol} / \mathrm{l}$. Yet, additional intrapituitary D2 inhibition with rT3 infusions (without a concomitant change of $\mathrm{T} 4$ infusion) does not result in the expected changes in serum TSH levels. The mechanisms that might be involved in this homeostatic adaptation remain to be clarified. We suggest that intrapituitary T4 concentrations, but also the circulating serum T3 levels, may be more important in long-term control of serum TSH than the absolute activity of pituitary D2.

\section{Acknowledgements}

This work was carried out thanks to grant 3100A0105889 from the Swiss National Science Foundation (Berne, Switzerland). We thank Mrs Ellen Kaptein (Erasmus University), Mrs Agnès Pernin and Dr JeanDaniel Graf (University of Geneva) for their excellent help. Our special thanks go to Professor Robert Utiger (Boston, MA, USA) who kindly reviewed the manuscript.

\section{References}

1 Larsen PR, Dick TE, Markovitz BP, Kaplan MM \& Gard TG. Inhibition of intrapituitary thyroxine to 3.5.3'-triiodothyronine conversion prevents the acute suppression of thyrotropin release by thyroxine in hypothyroid rats. Journal of Clinical Investigation $197964117-128$.

2 Christoffolete MA, Linardi CC, de Jesus L, Ebina KN, Carvalho SD, Ribeiro MO, Rabelo R, Curcio C, Martins L, Kimura ET \& Bianco AC. Mice with targeted disruption of the Dio2 gene have cold-induced overexpression of the uncoupling protein 1 gene but fail to increase brown adipose tissue lipogenesis and adaptive thermogenesis. Diabetes 200453 577-584.

3 Larsen PR, Silva JE \& Kaplan MM. Relationships between circulating and intracellular thyroid hormones: physiological and clinical implications. Endocrine Reviews 19812 87-102.
4 Bianco AC, Salvatore D, Gereben B, Berry MJ \& Larsen PR. Biochemistry, cellular and molecular biology, and physiological roles of the iodothyronine selenodeiodinases. Endocrine Reviews 200223 38-89.

5 Visser TJ, Kaplan MM, Leonard JL \& Larsen PR. Evidence for two pathways of iodothyronine $5^{\prime}$-deiodination in rat pituitary that differ in kinetics, propylthiouracil sensitivity, and response to hypothyroidism. Journal of Clinical Investigation $1983 \quad \mathbf{7 1}$ 992-1002.

6 Richard K, Hume R, Kaptein E, Sanders JP, van Toor H, De Herder WW, den Hollander JC, Krenning EP \& Visser TJ. Ontogeny of iodothyronine deiodinases in human liver. Journal of Clinical Endocrinology and Metabolism $1998 \mathbf{8 3} 2868-2874$.

7 Kohrle J. The selenoenzyme family of deiodinase isozymes controls local thyroid hormone availability. Reviews in Endocrine and Metabolic Disorders 20001 49-58.

8 St Germain DL \& Galton VA. The deiodinase family of selenoproteins. Thyroid $19977655-668$.

9 Morreale de Escobar G \& Escobar del Rey F. Maternal thyroid deficiency during pregnancy and subsequent neuropsychological development of the child [letter]. New England Journal of Medicine $19993412015-2016$ discussion 2017.

10 Morreale de Escobar G, Pastor R, Obregon MJ \& Escobar del Rey F. Effects of maternal hypothyroidism on the weight and thyroid hormone content of rat embryonic tissues, before and after onset of fetal thyroid function. Endocrinology $1985 \mathbf{1 1 7}$ 1890-1990.

11 Obregon MJ, Pascual A, Mallol J, Morreale de Escobar G \& Escobar del Rey F. Evidence against a major role of L-thyroxine at the pituitary level: studies in rats treated with iopanoic acid (telepaque). Endocrinology 1980106 1827-1836.

12 Schneider MJ, Fiering SN, Pallud SE, Parlow AF, St Germain DL \& Galton VA. Targeted disruption of the type 2 selenodeiodinase gene (DIO2) results in a phenotype of pituitary resistance to T4. Molecular Endocrinology 200115 2137-2148.

13 Nicod P, Burger A, Strauch G, Vagenakis AG \& Braverman LE. The failure of physiologic doses of reverse T3 to effect thyroid-pituitary function in man. Journal of Clinical Endocrinology and Metabolism $197643478-481$.

14 Shulkin BL \& Utiger RD. Reverse triiodothyronine does not alter pituitary-thyroid function in normal subjects. Journal of Clinical Endocrinology and Metabolism $1984 \mathbf{5 8} 1184-1187$.

Received 2 February 2005

Accepted 16 June 2005 